\title{
Leishmanicidal, antibacterial, and antioxidant activities of Caryocar brasiliense Cambess leaves hydroethanolic extract
}

\author{
Waldemar de Paula-Junior', Fabiana H. Rocha ${ }^{1}$, Lucélia Donatti², \\ Cyntia M.T. Fadel-Picheth ${ }^{1}$, Almeriane M. Weffort-Santos ${ }^{1 *}$
}

\author{
${ }^{1}$ Programa de Pós-graduação em Ciências Farmacêuticas, Universidade Federal do Paraná, Av. Prefeito Lothario \\ Meissner 632, 80210-170, Curitiba, PR, Brasil, \\ ${ }^{2}$ Departamento de Biologia Celular, Universidade Federal do Paraná, Av. Prefeito Lothario Meissner 632, \\ 80210-170, Curitiba, PR, Brasil
}

\begin{abstract}
RESUMO: “Atividades leishmanicida, bactericida e antioxidante do extrato hidroetanólico das folhas de Caryocar brasiliense Cambess". As atividades antimicrobiana e antioxidante do extrato hidroetanólico das folhas de Caryocar brasiliense foram estudadas. O extrato demonstrou efeito leishmanicida sobre formas promastigotas de Leishmania amazonensis e atividade bactericida sobre estirpes de bactérias patogênicas para o homem. Além disso, o extrato demonstrou relevante capacidade antioxidante, similar às atividades da vitamina $\mathrm{C}$ e da rutina.
\end{abstract}

Unitermos: Caryocar brasiliense, Caryocaraceae, piqui, atividade leishmanicida, atividade antioxidante, DPPH, leishmaniose.

\begin{abstract}
The antimicrobial and antioxidant activities of the hydroethanolic extract from Caryocar brasiliense leaves were evaluated. The extract showed leishmanicidal effect against Leishmania amazonensis promastigote forms and bactericidal activity against some pathogenic bacteria. The extract also showed relevant antioxidant activity, similar to that of vitamin $\mathrm{C}$ and rutin.
\end{abstract}

Keywords: Caryocar brasiliense, Caryocaraceae, piqui, leishmanicidal activity, antioxidant activity, DPPH, leishmaniasis.

\section{INTRODUCTION}

Leishmaniasis defines a group of diseases caused by species belonging to the genus Leishmania and is prevalent in 88 countries throughout the world (Desjeux, 1996). At least twenty species can be transmitted by the mosquito bites, originating cutaneous, diffuse cutaneous, mucocutaneous and visceral leishmaniasis in humans, dogs and various wild vertebrate hosts.

Leishmania spp. constitute a heterogeneous class of protozoans that have a digenetic life cycle, essentially requiring two different hosts to complete its biological cycle: first, an invertebrate insect vector, generally females of Phlebotomus or Luztomiya sand fly mosquito that bears the promastigote stage; then, a definitive host, sheltering the amastigote form, which can be represented by a human, dog or even a wild vertebrate.

Outside the mammalian host, the Leishmania life cycle is confined to the digestive tract of sand flies. Infection is initiated when mosquitos ingest vertebrate blood that contains macrophages infected with amastigotes. The infected bloodmeal passes to the posterior abdominal midgut. Thereafter, Leishmania parasites differentiate into several distinct promastigote developmental stages as they migrate from the posterior midgut to the stomodeal valve, which forms a junction with the foregut (Kamhawi, 2006). Each one of these stages is characterized by morphological and functional changes aimed at ensuring its survival in the mosquito.

As the sand fly feeds, promastigote forms of the parasite enter the human host via the proboscis. Within the human host, these forms are ingested by macrophages, where they metamorphose into amastigote forms, persisting in the hydrolytic environment of the phagolysosome for a long time, without being killed.

Following infection of host macrophages, the transformation from extracellular to intracellular parasites and concomitant adaptation to the widely differing host environments is achieved by a combination of morphological and biochemical changes (Leroux et al., 2006). Although the underlying molecular mechanisms are still poorly understood, the alternation between both stages basically depends on the expression of crucial stage-specific proteins (Walker et al. 2006), which are required for the metabolic adaptations to the different nutrient sources as well as for the morphological changes required for survival within the insect and mammalian hosts. 
Leishmaniasis can be controlled mainly in two ways, the elimination of the vector and the cure of the host. The first approach, although widely used, seems not to be efficient (Lacerda, 1994), leaving the therapeutic interventions as the major option. A third approach could be the elimination of the intermediary hosts, which is impractical, as many of them have not been so far identified.

As recently reviewed by Melby (2002), the main therapeutic alternatives against leishmaniasis are antimonials, pentamidine, amphotericin B, lipid associated amphotericin B (LAAMB), nifurtimox, mepacrine, allopurinol, aminosidine, metronidazole, ketoconazole, levamisole, gold derivatives and 8aminoquinolines. Despite all efforts employed in the search of new drugs, the oldest, still irreplaceable, drugs against leishmaniasis are stibo gluconate (Pentostam) and meglumine antimoniate (Glucantime) (Berman, 1988). These pentavalent antimonials deplete intracellular ATP levels due to interference with glycolysis and oxidation of fatty acids in amastigotes (Van Voorhis, 1990). Even with their toxicity, they are the first-line drugs to be used against this disease.

Despite the modern advances achieved in the field of synthetic chemistry, the most efficient drugs available have their genesis directly or indirectly related with the vegetal kingdom. Folk communities have long used plant extracts to treat illnesses (Morais et al., 2005; Vendruscolo et al., 2005). Many of these extracts have shown effective action, with new bioactive compounds being extracted and screened every year (Barbosa-Filho et al., 2005; barbosa-filho et al., 2006). These extracts have also proven to be good sources of therapeutic agents for the treatment of leishmaniasis (Carvalho; Ferreira, 2001; Rocha et al., 2005).

Caryocar brasiliense Cambess (Caryocaraceae) is a widely distributed Brazilian cerrado tree species (Collevatti et al., 2003; Araujo, 1995). Its fruits, popularly known as piqui, have been largely used in the cuisine of some states because of their high content in vitamins. The oil extracted from the fruits has several applications in the cosmeticindustry (Araujo, 1995), and therapeutically, ithas been used against influenza and lung diseases (Septímio, 1994; Siqueira, 1982). Leaves infusion has been used for liver disorders (Siqueira, 1982). Molluscicidal activity of the crude extract against Biomphalaria glabrata (Bezerra et al., 2002), trypanosomicidal activity of the ethanol extract against Trypanosoma cruzi (Herzog-Soares, 2002) and antifungal activity of the oil (Passos et al., 2002) have also been reported. Its oleanolic acid has shown ability to inhibit the growth of mouse sarcoma 180 (Oliveira et al., 1970).

In an attempt to further explore the biological potential of Caryocar brasiliense Cambess, the effects of the hydroethanolic extract of the leaves were tested against Leishmania amazonensis promastigotes, and some pathogenic bacteria and fungi species. Also, the antioxidant property of this extract was investigated and compared to two known antioxidants, vitamin $\mathrm{C}$ and rutin.

\section{MATERIAL AND METHODS}

\section{Plant material and extract preparation}

Leaves of Caryocar brasiliense Cambess collected in the surrounding areas of Montes Claros, Minas Gerais state, in June 2003, were identified by Professor O. A. Guimarães, from the Botany Department, Universidade Federal do Paraná, Curitiba, Paraná, at which a voucher specimen has been deposited under the Protocol 46279. The hydroethanolic extract was obtained by extraction of the dried leaves $(850 \mathrm{~g})$ with $25 \% \mathrm{EtOH}(1650 \mathrm{ml})$ for three days at room temperature. The resulting solution was filtered, evaporated to dryness in a rotary evaporator at $45 \mathrm{rpm}, 60^{\circ} \mathrm{C}$ and then lyophilised, aliquoted, and stored at $-20^{\circ} \mathrm{C}$. Just before the experiments, solutions of the powdered extract were prepared in aqueous medium according to the assay to be performed, and filter-sterilised (Acrodisc, $0.22 \mu \mathrm{m}$ ). Standard phytochemical screening of the extract showed the presence of flavonoids, tannins, saponins, and terpenoids.

\section{Leishmanicidal activity}

At the exponential growth, suspension of promastigote forms $\left(10^{6}\right.$ parasites $\left./ \mathrm{ml}\right)$ of $L$. amazonensis (ICLA/BR/67/PH3) in RPMI 1640 supplemented with $10 \%$ FCS (Gibco) was added of 2.5 and $5.0 \mathrm{mg} / \mathrm{mL}$ of extract, or Glucantime $(60 \mathrm{mg} / \mathrm{ml})$ and kept at $27^{\circ} \mathrm{C}$ for 24 and 72 hours. Growth was evaluated by counting the number of cells in a hemocytometer after the incubation periods. Viability was evaluated by the eosin/nigrosin standard staining (O.M.S., 1994).

\section{Antibacterial activity}

Antibacterial activity was evaluated according to the standard procedures recommended by the NCCLS (2000), using the agar diffusion method against Enterococcus faecalis (ATCC 29212), Escherichia coli (ATCC 25922), Pseudomonas aeruginosa (ATCC 27853), and Staphylococcus aureus (ATCC 25923) strains. Standard antibiotic disks (6 $\mathrm{mm}$ diameter) were wetted with $10 \mu \mathrm{L}$ of extract solutions at $1.0,1.5$, and $2.0 \mathrm{mg} / \mathrm{mL}$, and were deposited onto surface of Mueller-Hinton agar plates having $0.5 \mathrm{McF}$ arland bacteria inocula previously applied, along with recommended antibiotics disks for each bacteria strain. After 24 hours at $36{ }^{\circ} \mathrm{C}$, inhibition zones were measured in millimeters. Microdilution test was performed with the aim of establishing the minimum inhibitory concentration (MIC) and the procedure undertaken was precisely as previously described in 
the NCCLS M7-A5 standard (2000). Colonies were taken from overnight agar plates, and sterile saline was inoculated to make a $0.5 \mathrm{McF}$ arland suspension inoculum. The MIC endpoint was the lowest concentration of extract that completely inhibited the visible growth.

\section{Antioxidant activity}

Antioxidant activity was measured by the 2,2-diphenyl-1-picrylhydrazyl (DPPH) stable radical method in $\mathrm{MeOH}$ solution, according to Brandwilliams et al, (1995). Briefly, the extract was diluted to final concentrations ranging from $10^{-4}$ to $10 \mathrm{mg} / \mathrm{mL}$ in ethanol. A total of $1 \mathrm{~mL}$ of a $0.3 \mathrm{mM}$ DPPH ethanolic solution was added to $2.5 \mathrm{~mL}$ of sample solution and allowed to react at room temperature. After $30 \mathrm{~min}$, the absorbance (A) was measured at $518 \mathrm{~nm}$ (Shimadzu UV-1601) and converted into percentage of antioxidant activity using the following equation: $\%$ scavenging capacity $=100$ - $\left[\left(\mathrm{A}_{\text {sample }}-\mathrm{A}_{\text {blank }}\right) \times 100\right] / \mathrm{A}_{\text {control }}$ (Mensoret al., 2001). Ethanol $(1.0 \mathrm{~mL})$ plus extract solution $(2.5 \mathrm{~mL})$ were used as a blank, while DPPH solution plus ethanol were used as a negative control. The results are also presented as radical scavenger capacity, expressed as $\mathrm{EC}_{50}$, which is the amount of antioxidants necessary to decrease the initial $\mathrm{DPPH} \cdot$ absorbance by $50 \%$, and was calculated by linear regression of plots, where the abscissa $(x)$ represented the tested extract concentrations, and the ordinate $(y)$, the average percent of scavenging capacity from triplicates. Solutions of vitamin $\mathrm{C}$ and rutin were prepared in similar concentrations and used as antioxidant standards.

\section{Ultrastructural analysis}

Control and treated promastigote forms of L. amazonensis were collected by centrifugation after incubation, washed in PBS, fixed with modified Karnovsky's solution (4\% paraformaldehyde, 2.5\% glutardialdehyde in $0.1 \mathrm{M}$ sodium cacodylate buffer, $\mathrm{pH}$ 7.2), transferred onto poly-L-lysine-coated glass coverslips and allowed to settle. The cells were then dehydrated in a graded ethanol series from $90 \%$ to $100 \%$ and critical point dried in a Bal-tec CPD 030 Critical Point Dryer. The samples were sputter coated with gold in a SDC 030 Balzers union FL 9496 instrument, and examined in a JSM $6360 \mathrm{LV}$ electron microscope at 10 $\mathrm{kV}$.

\section{Statistical evaluation}

Whereas convenient the results are expressed as the mean \pm SD of triplicates of at least three independent experiments. Statistical significance was calculated by ANOVA followed the Tukey test, and differences were considered significant when $p \leq 0.05$.

\section{RESULTS}

The hydroethanolic extract prepared from the Caryocar brasiliense Cambess leaves inhibited the proliferation of promastigote forms of L. amazonensis in a dose- and time-related manner (Table 1). Interestingly, this effect was significantly superior to the effects showed by Glucantime, the drug of choice for the treatment of leishmaniasis, as mentioned earlier. Although parasites could be recovered from the cultures, their survival was highly compromised as shown by the significantly low viability after eosin/nigrosin staining, particularly at 5 $\mathrm{mg} / \mathrm{mL}$.

In order to confirm this remarkable cytotoxic effect, the contents of the 72 hours culture were replated in fresh medium, and incubated for an extended period of 24 hours at the same culture conditions, but no microorganism growth or revitalization could be observed. Also, only the plant extract treatment caused deep damage to the parasites, which could be easily observed by both light (data not shown) and scanning electron microscopy (Figure 1).

The effects of the extract upon gram positive and gram negative pathogenic bacteria strains assayed are summarized in Table 2. Although inhibition of growth was observed for all bacteria included in this study, the best activity was observed against $P$. aeruginosa at 1.5 and $2.0 \mathrm{mg} / \mathrm{mL}$, followed by $S$. aureus. As the medium

Table 1. Leishmanicidal activity of Caryocar brasiliense leaves extract.

\begin{tabular}{|c|c|c|c|c|c|c|c|c|c|c|c|}
\hline \multirow{3}{*}{ Protozoan } & \multicolumn{6}{|c|}{ Concentration $(\mathrm{mg} / \mathrm{ml}) /$ Promastigote $\left(\times 10^{6}\right)$} & \multicolumn{5}{|c|}{ Cell Viability $(\%)^{\mathrm{d}}$} \\
\hline & \multicolumn{3}{|c|}{2.5} & \multicolumn{3}{|c|}{5.0} & \multicolumn{2}{|c|}{2.5} & \multicolumn{3}{|c|}{5.0} \\
\hline & $24 \mathrm{~h}^{a}$ & $72 \mathrm{~h}$ & $96 \mathrm{~h}^{*}$ & $24 \mathrm{~h}$ & $72 \mathrm{~h}$ & $96 \mathrm{~h} *$ & $24 \mathrm{~h}$ & $72 \mathrm{~h}$ & $24 \mathrm{~h}$ & $72 \mathrm{~h}$ & $96 \mathrm{~h}^{*}$ \\
\hline L. amazonensis & $1.6 \pm 0.5^{\#}$ & $0.9 \pm 0.2^{\#}$ & none & $1.1 \pm 0.8$ & $0.3 \pm 0.2$ & none & $12.3 \pm 1.5^{\#}$ & $4.8 \pm 1.0^{\#}$ & $<1$ & none & none \\
\hline Glucantime $^{\mathrm{b}}$ & $3.0 \pm 1.3^{\#}$ & $2.2 \pm 0.3^{\#}$ & & & & & $39.8 \pm 0.8^{\#}$ & $10.4 \pm 2.1^{\#}$ & & & \\
\hline Control $^{\mathrm{c}}$ & $10.6 \pm 1.6$ & $122 \pm 21.5$ & & & & & $95.8 \pm 2.7$ & $96.3 \pm 1.8$ & & & \\
\hline
\end{tabular}

${ }^{a}$ Values are the mean $\pm \mathrm{SD}$ of triplicates from three independent experiments. $\# p<0.0001$.

${ }^{\mathrm{b}}$ Recommended drug, at $60 \mathrm{mg} / \mathrm{ml}$.

${ }^{\mathrm{c}}$ No treatment.

${ }^{\mathrm{d}}$ Eosin/nigrosin staining.

* replating of the $72 \mathrm{~h}$ cultures. 

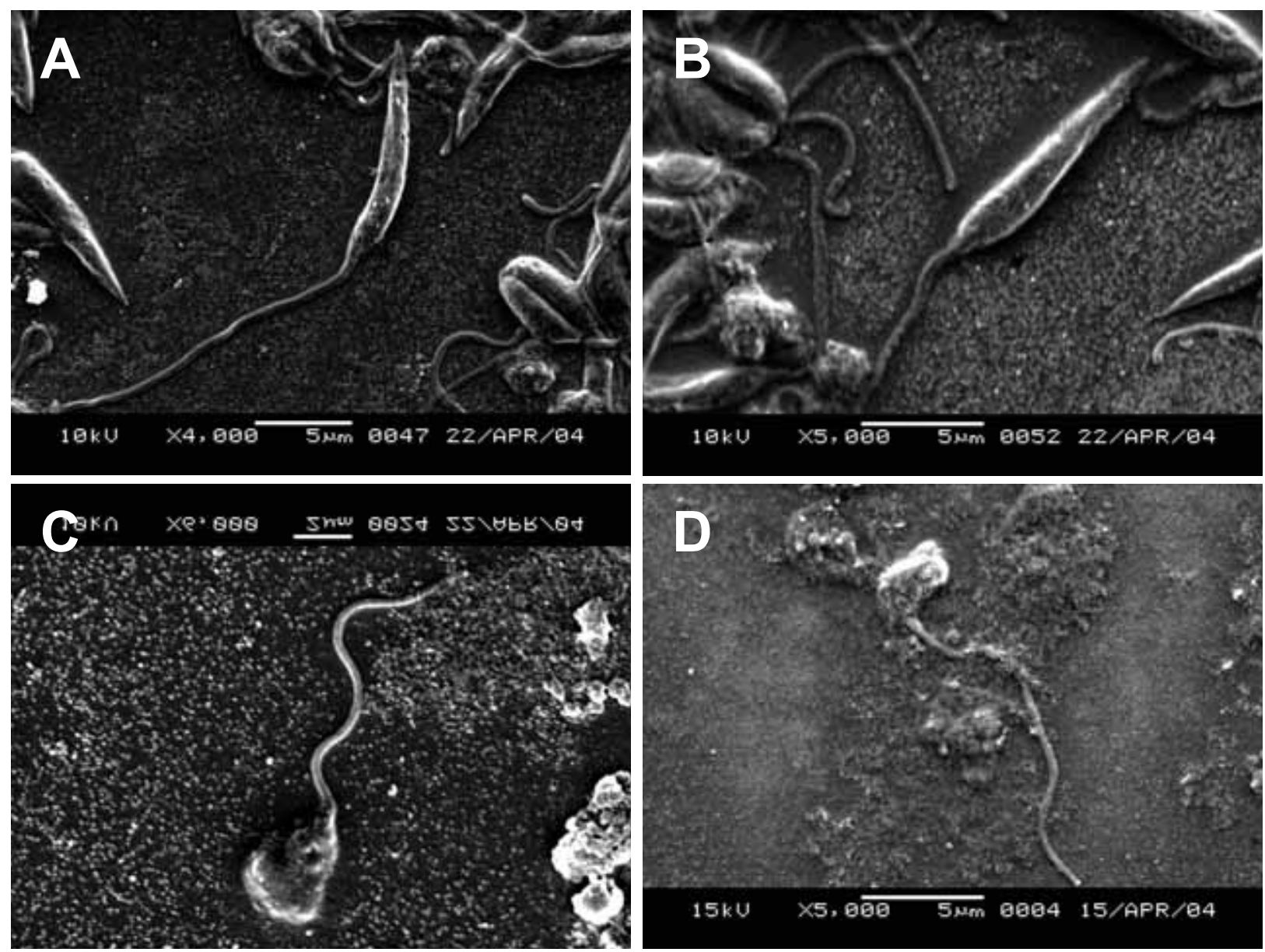

Figure 1. Scan electron microscope micrograph of L. amazonensis promastigote forms appearance before (A) and after (B) 72 hours of treatment with glucantime, 2.5 (C) and $5.0 \mathrm{mg} / \mathrm{ml}$ (D) of Caryocar brasiliense Cambess leaves extract.

Table 2. Antibacterial activity of Caryocar brasiliense leaves extract.

\begin{tabular}{lccccccc}
\hline \multirow{2}{*}{ Bacteria } & \multicolumn{6}{c}{ Concentration $(\mathrm{mg} / \mathrm{ml}) /$ Inhibition zone $(\mathrm{mm})^{\mathrm{a}, \mathrm{b}}$} \\
\cline { 2 - 8 } & $\mathrm{G}$ & 1.0 & 1.5 & 2.0 & \multicolumn{2}{c}{ Reference Drug } \\
\hline Escherichia coli & $(-)$ & - & 7 & 8 & Ticarcilin + & $85 / 25-29$ \\
Pseudomonas aeruginosa & $(-)$ & 10 & 15 & 15 & Clavulanic Acid & $5 / 20-28$ \\
Enterococcus faecalis & $(+)$ & - & 7 & 8 & Trimetropin & $25 />20$ \\
Staphylococcus aureus & $(+)$ & 8 & 9 & 12 & sulfamethoxazole & Meropenem & $10 / 29-37$ \\
\hline
\end{tabular}

${ }^{a}$ Values are the average of triplicates. G: bacteria gram reaction. (-) no inhibition.

${ }^{b}$ Includes the diameter of the bore $(6 \mathrm{~mm})$.

${ }^{\mathrm{c}}$ Standard drug concentration and values recommended by the NCCLS.

turned blurred with increasing extract concentration, MIC values of $4 \mathrm{mg} / \mathrm{mL}$ could be established only for E. coli and S. aureus. Despite these effects, none of the extract doses assayed had the performance showed by the recommended antibiotics.

The antioxidant activity of $C$. brasiliense leaves extract evaluated by the DPPH method is presented in Table
3. The results indicate a potent antioxidant activity of the extract, which at the concentration of $1.0 \mathrm{mg} / \mathrm{mL}$, was very close to that presented by vitamin $\mathrm{C}$ and rutin. Moreover, there was no difference in the amount of extract, vitamin $\mathrm{C}$ or rutin to reduce $50 \%$ the DPPH initial concentration $\left(\mathrm{EC}_{50}\right)$, suggesting that the antioxidant potential of the $C$. brasiliense extract is similar to that presented by vitamin 
Table 3. Antioxidant potential of the Caryocar brasiliense Cambess leaves hydroethanolic extract evaluated by the DPPH radical.

\begin{tabular}{|c|c|c|c|c|c|c|c|}
\hline \multicolumn{2}{|c|}{$\begin{array}{c}\text { Concentration } \\
(\mathrm{mg} / \mathrm{ml})\end{array}$} & 0.0001 & 0.001 & 0.01 & 0.1 & 1.0 & $\mathrm{EC}_{50}$ \\
\hline \multirow{3}{*}{$\mathrm{IP}^{\mathrm{a}}(\%)$} & Extract & ND & ND & $7.49 \pm 0.19$ & $93.35 \pm .45$ & $93.15 \pm 0.71$ & 0.058 \\
\hline & Rutin & $27.37 \pm 0.17$ & $32.63 \pm 0.35$ & $34.87 \pm 0.27$ & $68.0 \pm 0.43$ & $93.32 \pm 0.65$ & 0.053 \\
\hline & Vit C & ND & ND & $1.44 \pm 0.06$ & $95.12 \pm 0.22$ & $95.86 \pm 0.35$ & 0.057 \\
\hline
\end{tabular}

a Values are the mean $\% \pm \mathrm{SD}$ of three experiments run in triplicates.

IP: Percent of radical scavenging capacity.

ND: not done.

$\mathrm{C}$, a natural water-soluble compound frequently used as a model for comparing antioxidant activity, or by rutin, a natural occurring flavonoid well known by its potent antioxidant properties.

\section{DISCUSSION}

In this study, we have investigated the ability of the hydroethanolic extract prepared from the $C$. brasiliense leaves in interfering with the growth of different groups of pathogenic microorganisms for humans. The data herein presented have shown that it could not only inhibit the development of some common pathogenic bacteria but was also able to remarkably kill promastigote forms of $L$. amazonensis. Of particular interest, it has revealed a high antioxidant potential, similar to that of vitamin $\mathrm{C}$ and, particularly to rutin, a natural occurring flavonoid well known by its antioxidant properties (Hanasaki et al., 1994).

These findings are of particular relevance in clinical practice as cutaneous leishmaniasis is characterized by ulcerative skin lesions, comprising a large spectrum of manifestations, varying from single or limited lesions to diffuse cutaneous and muco-cutaneous disease, which are often further compromised by the association with common pathogenic bacteria.

Infection and inflammation activate a variety of inflammatory cells that induce and activate several oxidant-generating enzymes that produce high concentrations of different free radicals and oxidants, including the superoxide anion, nitric oxide, nitroxyl, nitrogen dioxide, hydrogen peroxide and hypochlorous acid. These reactive oxygen and nitrogen species (ROS and RNS) are an important part of host-defense strategies of organisms to kill parasites (Saran et al., 1999) as they react with each other to produce other reactive species that are sometimes more efficient than the oxidants themselves (Beckman; Koppenol, 1996). In this context, it has been recently suggested that ROS and RNS produced as a defense strategy may amplify the leishmanicidal activity in patients with cutaneous leishmaniasis (Kocyigit et al., 2005). However, excessive amounts of these reactive species in inflamed tissues can cause injury to host cells and induce DNA damage and mutations by the same reactions (Dizdaroglu, 1994).

Thus, besides broadening the biological spectrum of this cerrado plant, the results presented have also provided new perspectives on drug development against Leishmaniasis. Further research is needed to explore the biological properties presented by the $C$. brasiliense leaves extract in in vivo models, verifying whether the association of the antimicrobial activities with the free radical scavenger effects would have a double advantage in topical formulations: on one hand, it could eliminate leishmania while preventing contamination with bacteria, and on the other hand, it could limit the free radical damages generated from the inflammatory response, favoring tissue healing.

\section{ACKNOWLEDGMENTS}

The authors gratefully acknowledge Professor O. A. Guimarães collaboration on the plant identification, Rene Rachou Research Center, for the L. amazonensis strain, and S. M. P. Alves, CEMEPAR-PR, for Glucantime.

\section{REFERENCES}

Araujo FD 1995. A review of Caryocar brasiliense (Caryocaraceae) - an economically valuable species of the Central Brazilian Cerrados. Econ Bot 49: 40-48.

Barbosa-Filho JM, Vasconcelos THC, Alencar AA, Batista LM, Oliveira RAG, Guedes DN, Falcão HS, Moura MD, Diniz MFFM, Modesto-Filho J 2005. Plants and their active constituents from South, Central, and North America with hypoglycemic activity. Rev Bras Farmacogn 15: 392-413.

Barbosa-Filho JM, Medeiros KCP, Diniz MFFM, Batista LM, Athayde-Filho PF, Silva MS, Cunha EVL, Almeida JRGS, Quintans-Júnior LJ 2006. Natural products inhibitors of the enzyme acetylcholinesterase. Rev Bras Farmacogn 16: 258-285.

Beckman JS, Koppenol WH 1996. Nitric oxide, superoxide, and peroxynitrite: the good, the bad, and ugly. Am J Physiol 271: C1424-1437.

Berman JD 1988. Chemotherapy for leishmaniasis: biochemical mechanisms, clinical efficacy, and future strategies. Rev Infect Dis 10: 560-586.

Bezerra JCB, Silva IA, Ferreira HD, Ferri PH, Santos SC 2002. 
Molluscicidal activity against Biomphalaria glabrata of Brazilian cerrado medicinal plants. Fitoterapia 73: 428-430.

Brandwilliams W, Cuvelier ME, Berset C 1995. Use of a freeradical method to evaluate antioxidant activity. Food Sci Technol Lebensmittel-Wissenschaft \& Technologie 28: 25-30.

Carvalho PB, Ferreira EI 2001. Leishmaniasis phytotherapy. Nature's leadership against an ancient disease. Fitoterapia 72: 599-618.

Collevatti RG, Grattapaglia D, Hay JD 2003. Evidences for multiple maternal lineages of Caryocar brasiliense populations in the Brazilian cerrado based on the analysis of chloroplast DNA sequences and microsatellite haplotype variation. Mol Ecol 12: 105115.

Desjeux P 1996. Leishmaniasis: public health aspects and control. Clin Dermatol 14: 417-423.

Dizdaroglu M 1994. Chemical determination of oxidative DNA damage by gas chromatography-mass spectrometry. Methods Enzymol 234: 3-16.

Hanasaki Y, Ogawa S, Fukui S 1994. The correlation between active oxygens scavenging and antioxidative effects of flavonoids. Free Radic Bio Med 16: 845-850.

Herzog-Soares JD, Alves RK, Isac E, Bezerra JCB, Gomes MH, Santos SC, Ferri PH 2002. Atividade tripanocida in vivo de Stryphnodendron adstringens (barbatimão verdadeiro) e Caryocar brasiliensis (pequi). Rev Bras Farmacogn 12(Supl. 1): 1-2

Kamhawi, S 2006. Phlebotomine sand flies and Leishmania parasites: friends or foes? Trends Parasitol 22, 439445.

Kocyigit A, Keles H, Selek S, Guzel S, Celik H, Erel O 2005. Increased DNA damage and oxidative stress in patients with cutaneous leishmaniasis. Mutat Res 585: 71-78.

Lacerda MM 1994. The Brazilian leishmaniasis control program. Mem I Oswaldo Cruz 89: 489-495.

Leroux, A, Fleming-Canepa, X, Aranda, A, Maugeri, D, Cazzulo, JJ, Sanchez, MA, Nowicki, C 2006. Functional characterization and subcellular localization of the three malate dehydrogenase isozymes in Leishmania spp. Mol Biochem Parasitol 149: 74-85.

Melby PC 2002. Recent developments in leishmaniasis. Curr Opin Infect Dis 15: 485-490.

Mensor LL, Menezes FS, Leitao GG, Reis AS, dos Santos TC, Coube CS, Leitao SG 2001. Screening of Brazilian plant extracts for antioxidant activity by the use of DPPH free radical method. Phytother Res 15: 127130.

Morais SM, Dantas JDP, Silva ARA, Magalhães EF 2005. Plantas medicinais usadas pelos índios Tapebas do Ceará. Rev Bras Farmacogn 15: 169-177.

National Committee for Clinical Laboratory Standards 2000. Methods for dilution antimicrobial susceptibility tests for bacteria that grow aerobically. Approved standard M7-A5. National Committee for Clinical Laboratory Standards, Villanova, $\mathrm{Pa}$.

Oliveira MM, Sampaio RP, Giorgi W, Gilbert B, Mors WB 1970. Caryocar brasiliense - isolamento e identificação de algumas substâncias: atividade biológica sobre o sarcoma 180. Arquivos do Instituto Biológico 37 Supl I: $25-27$.

O.M.S. 1994. Manual de laboratório para o exame do sêmen humano e interação esperma-muco cervical. São Paulo: Livraria Santos Editora.

Passos XS, Santos SC, Ferri PH, Fernandes OF, Paula TF, Garcia AC, Silva MR 2002. Antifungal activity of Caryocar brasiliensis (Caryocaraceae) against Cryptococcus neoformans. Rev Soc Bras Med Trop 35: 623-627.

Rocha LG, Almeida JRGS, Macedo RO, Barbosa-Filho JM 2005. A review of natural products with antileishmanial activity. Phytomedicine 12: 514-535.

Saran M, Beck-Speier I, Fellerhoff B, Bauer G 1999. Phagocytic killing of microorganisms by radical processes: consequences of the reaction of hydroxyl radicals with chloride yielding chlorine atoms. Free Radic Bio Med 26: 482-490

Septímio LR 1994 A fitoterapia baseada em ervas medicinais do cerrado. SIPE-Ministério da Cultura, Brasil.

Siqueira JC 1982. Plantas do cerrado na medicina popular. Spectrum J Bras Ci 2: 41.

Van Voorhis WC 1990. Therapy and prophylaxis of systemic protozoan infections. Drugs 40: 176-202.

Vendruscolo GS, Rates SMK, Mentz LA 2005. Dados químicos e farmacológicos sobre as plantas utilizadas como medicinais pela comunidade do bairro Ponta Grossa, Porto Alegre, Rio Grande do Sul. Rev Bras Farmacogn 15: 361-372.

Walker J, Vasquez JJ, Gomez MA, Drummelsmith J, Burchmore R, Girard I, Ouellette M. 2006. Identification of developmentally-regulated proteins in Leishmania panamensis by proteome profiling of promastigotes and axenic amastigotes. Mol Biochem Parasitol 147: 64-73. 